mended no eggs have gone down, we have concluded that it is natural for cod-eggs to float, and that under no other conditions will normal development be accomplished. JOHN A. RYDER.

Wood's Holl, Dec. 21.

\section{CLOSE APPROACH OF SATURN AND GEMINORUM.}

ON the night of 1886 Jan. 9 (or morning of the 10th, civil time) there will occur a very close approach of the planet Saturn to the star $\mu$ Geminorum, whose magnitude is given as 3.22 in the Harvard photometry. The figure below gives the relative configurations of planet and star for successive hours of Greenwich mean time (astronomical) as seen in the ordinary inverting telescope.
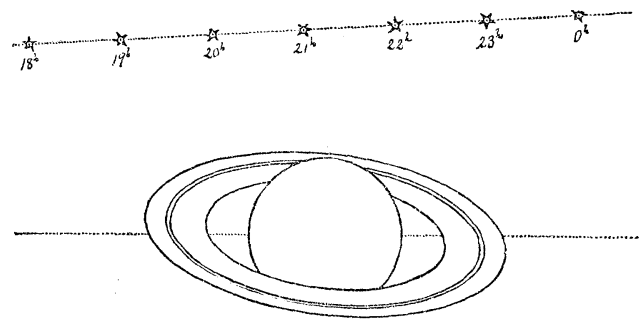

To see it as it will appear to the naked eye, with an opera or field glass, or with a telescope having a terrestrial eyepiece, turn the diagram bottom upwards. At the time of nearest approach to the centre of the ball (a little after $21^{\mathrm{h}}$ ) the star will be about $26^{\prime \prime}$ from the centre, or $16^{\prime \prime}$ from the edge of the ball. For convenience the planet is figured as stationary, and the star as moving by it. Of course, the planet (as seen in the telescope) moves to the left, parallel to the line through the successive positions of the star. The dotted line through the planet's centre is parallel to the earth's equator, and makes an angle of $6^{\circ} 35^{\prime}$ with the major axis of the rings. The time of nearest approach is about five hours after the transit over the meridian of Washington, and is well visible over the whole of this country, though of course best for the Pacific slope, where it will not be so far down in the west. To convert the times given above into the standard civil times, add $7^{\mathrm{h}}, 6^{\mathrm{h}}, 5^{\mathrm{h}}$, and $4^{\mathrm{h}}$ respectively, subtracting $24^{\mathrm{h}}$ if necessary, which carries it into the civil day of Jan. 10.

Astronomically the event is of very little importance compared with what an actual occultation by the ring, or by the ring and ball, would be. A star as bright as this, and behind the rings, would offer a test we have never had yet of their possible transparency through interstices in the probable cloud of satellites. The action of the dusky ring (not indicated above) would be especially interesting. A central occultation by the ball would give, by means of micrometric measures and the duration of the occultation, a sharp test of the refracting power of Saturn's atmosphere, and the possible semi-transparency of its upper cloudsurface. So near an approach of Saturn to a star as bright as the 3.22 magnitude is an exceedingly rare event. Assuming that the distribution : $f$ f stars brighter than the 3.22 magnitude along Saturn's path is the same as the average, we find that only once in 612 years will Saturn approach so near one of them as on $1886 \mathrm{Jan} .9$. Of course, actual occultations will be still more rare, and only likely to occur by the ring once in about 1,730 years, and by the ball only once in a little over 2,000 years. So near and yet so far from an actual occultation is the coming event.

H. M. PAUL.

\section{THE CONVICT-LABOR PROBLEM.}

THE attention of philanthropists and students of social science, which has for a long time past been turned toward this subject, has been increased of late by the attitude of the labor agitators. Perhaps not more than one out of every ten thousand laboring men gives the question of convictlabor competition a thought, but this odd one has during the last decade managed to stir up a great deal of discussion.

That convicts should be employed, and employed, if possible, in a manner profitable to the state, is a proposition that no sane man.controverts. Now, there are various ways of employing convicts; and the agitators insist that one of these ways - the one, it so happens, which has in the past produced the largest revenue to the statehas an injurious effect upon the honest laborer by compelling him to submit to an unfair competition. Strange to say, this clamor has had some effect; though how sixty thousand convicts, - the whole number in the United States, according to the last census, - working as they do under peculiarly disadvantageous circumstances, and consisting of the lowest and most ignorant classes of the population, can effect any appreciable competition with the millions of honest and free workingmen, it is difficult to conceive. Those who join in this outcry are to a great extent communists, and leaders of labor organizations, whose sustenance depends upon the amount of agitation they can create, together with such political aspirants as aid them for purely selfish purposes.

The effect of all these elements combined has been visible in the statute-books of several states. Among these is New Jersey, whose legislature 
passed a law, Feb. 21, 1884, abolishing the system of contracting for the labor of prisoners at so much per day, and followed it up with a law, dated April 18 of the same year, directing the introduction of the 'public-account' or 'piece-price' plan, as the prison authorities should decide. The contract system, it was claimed, was the source of the unfair competition complained of, and these laws were passed under the agitators' influence expressily to prevent such competition.

The new law took effect on the expiration of the old contracts, in July, 1885, and in the reports of the prison officials for the current year we have a summary of the results obtained thus far; and, inasmuch as several states are having the same experience as New Jersey, the conclusions reached by her officials in this matter are of general political as well as scientific interest.

The 'public-account' plan was so generally discredited, that the officials adopted the other alternative under the law; namely, the 'piece-price'. plan. Under this system, the contractor pays a fixed price per dozen, gross, or thousand for work done on materials furnished by him. The introduction of this radically new system occasioned some delay for the purchase of machinery, fittingup of shops, etc., and the authorities are cautious enough to state that their experience of the new system has been too limited to admit of unqualified indorsement or condemnation. Nevertheless, all the facts and figures presented in these reports point in the same direction. They prove that not only does the state treasury lose largely by the change from the old contract system, but that the contractors are enabled to put their goods on the market at a less cost for manufacturing than ever before; so that, as far as there is any competition with free labor, it is greater under the ' piece-price' plan than it was before. This is a result which reflects upon the sagacity of the agitators themselves; for, if their pet system can be proved injurious on so short a trial, their stock in trade is exhausted.

One contractor who under the former system paid fifty cents per day for the labor of every convict, skilful or unskilful, who went into his shops, now averages less than half that sum per convict. In one or two cases the contractors now pay a few more cents per day's labor than formerly, but this apparent gain results from greatly increasing the quantity of the work; so that, even with an apparently similar financial result to the state, the product is manufactured cheaper now than under the contract system.

These early conclusions from this new departure are interesting. They show that the labor agitators are many, and the mass of political scientists and humanitarians are right in upholding the contract system as the best and most profitable for the employment of convict-labor. Reasonable limitations to the operation of the contract system may very possibly be suggested by experience; but these data from New Jersey ought to insure the rejection of the 'piece-price' plan everywhere, or else some radical modifications in its details.

Nicholas Murray Butler.

\section{NOTES AND NEWS.}

THERE is not much to be said of the popularscience articles in the December magazines, for there are not many of them ; and what there are, are very popular, though quite interesting. The Atlan$t i c$ adds another to the already long list of reviews on the recent ' Life of Agassiz,' but fails to say, what seems tolerably obvious, that the time has not yet come when the value of Agassiz's scientific labors, or indeed of his influence on the progress of natural history in the United States, can be correctly estimated. John Burrows, in the Century, gives, in very readable form, some notes on bird enemies, - jays, owls, vermin, mice, snakes, and 'collectors.' In Harpers' magazine there is a highly aesthetic article called 'A winter walk.' It is beautifully illustrated, and well adapted to the wants of ladies of scientific turn of mind. Perhaps the author tried to imitate Thoreau; but if he did, he failed. To persons interested in ornithology, $\mathrm{Mr}$. Edward C. Bruce's article in Lippincott's magazine, on 'Birds of a Texan winter,' will doubtless be entertaining. After mentioning a few of our birds that do not migrate, Mr. Bruce goes on to tell us of the northern birds he has seen in Texas during the winter, - plovers, herons, wild geese, etc. The English magazines have even less than the American on natural science this month. There are only two articles to be mentioned. One is by Benjamin Kidd, in Longman's magazine, on the 'Humble-bee,' and gives some description of the habits of this insect, based, it would seem, largely on the author's personal observation. The other is by W. Mattieu Williams, in the Gentleman's magazine, and is called 'Science notes.' The topics dealt with are, the origin of boracic acid, meteoric explosions, magnetic sifting of meteorites, fireproof paper structures, the future of the negro, the sleep of fishes, and icebergs and climate.

- The dog by which Kaufmann, who is now in Paris for treatment under Pasteur, was bitten, is shown conclusively to have been mad, a dog bitten by it nearly at the same time having since died of unmistakable rabies.

- Prof. Edward Süss delivered in the Geo- 